\title{
The $m t / D$ Gene-overexpressed Transgenic Wheat Tolerates Salt Stress Through Accumulation of Mannitol and Sugars
}

\author{
Mohamed Ahmed Seif El-Yazal ${ }^{1}$, Hala Fawzi Eissa ${ }^{2}$, Safia Mahmoud Abd El-Mageed Ahmed ${ }^{1}$, \\ Saad Mohamed Howladar ${ }^{3}$, Safi-naz Sabet Zaki ${ }^{4}$, Mostafa Mohamed Rady ${ }^{1}$ \\ ${ }^{1}$ Botany Department, Faculty of Agriculture, Fayoum University, Fayoum, Egypt \\ ${ }^{2}$ Agricultural Genetic Engineering Research Institute (AGERI), Agriculture Research Center (ARC), Giza, Egypt \\ ${ }^{3}$ Biology Department, Faculty of Sciences, Albaha University, Albaha, Saudi Arabia \\ ${ }^{4}$ Department of Water Relations and Field Irrigation, National Research Centre, Dokki, Cairo, Egypt
}

Email address:

mmr02@fayoum.edu.eg (M. M. Rady), mrady2050@gmail.com (M. M. Rady)

\section{To cite this article:}

Mohamed Ahmed Seif El-Yazal, Hala Fawzi Eissa, Safia Mahmoud Abd El-Mageed Ahmed, Saad Mohamed Howladar, Safi-naz Sabet Zaki, Mostafa Mohamed Rady. The $m t l D$ Gene-overexpressed Transgenic Wheat Tolerates Salt Stress Through Accumulation of Mannitol and Sugars. Plant. Vol. 4, No. 6, 2016, pp. 78-90. doi: 10.11648/j.plant.20160406.15

Received: September 17, 2016; Accepted: October 12, 2016; Published: October 31, 2016

\begin{abstract}
The $m t l D$ gene-contained transgenic wheat has established the role of mannitol and sugars accumulation in alleviating the abiotic stresses, including salinity. This study was conducted to determine whether the $85 \mathrm{mM} \mathrm{NaCl}$-salinity could be tolerated by wheat (genotype 235/3) plants of which seeds were transformed with mtlD gene (from Escherichia coli). The effects of $m t l D$ gene transformation into wheat seeds on growth traits, physio-biochemical attributes, and yield and its quality of transgenic wheat genotype were investigated compared to non-transgenic wheat genotype under $85 \mathrm{mM} \mathrm{NaCl}-$ salinity. Results showed that $m t l D$ gene-contained transgenic plants had improved salt tolerance over non-transgenics, showing by better growth traits (i.e., number of leaves and leaf area per plant, root system size and plant dry weights), physiobiochemical attributes (i.e., levels of leaf chlorophylls, shoot free proline, total soluble sugars, soluble sugar fractions and mannitol, activities of enzymatic and non-enzymatic antioxidants, and contents of nutrient elements), yield (i.e., number of spikes and grain weight per plant, and 1000-grain weight) and yield quality (i.e., grain contents of starch, protein and soluble sugars). The $m t l D$ gene transformation into wheat seeds appears to a better strategy to increase salt tolerance of plants through increased performance of mannitol and sugar accumulation, showing more of their salt stress-protecting role. The best performing $m t l D$ transgenics could be incorporated in a breeding program to accumulate transgenes for stress tolerance in elite wheat genotypes in a step to commercialize these transgenics with the proper level of salt tolerance.
\end{abstract}

Keywords: Physio-Biochemical Attributes, Salt Stress, Transgenic Wheat, Yield and Its Quality

\section{Introduction}

Loss of arable land via salinization is a major factor undermining the productivity of modern agricultural systems (Galvani, 2007). Salinization of agricultural soils occurs primarily due to agricultural practices, including poor water management, high evaporation, heavy irrigation and previous exposure to sea water (Pitman and Lauchli, 2002). This constant salinization of arable land is expected to have overwhelming global effects, resulting in $50 \%$ land loss by the year 2050 (Wang et al., 2003). This loss in arable land with steadily increasing of global population generates a great gap between the produced agricultural food and the global population.

Saline soils retard growth of most plants, therefore, it is necessary to breed stress-tolerant plants to grow well under salt stress. Despite most of the research community members had claimed that salt tolerance implies the differential gene expression of thousands of genes (Munns and Tester, 2008; Sanchez et al., 2008), numerous developments have been reported in generating plants using transgenic technology where over-expressing a single gene has conferred high salinity tolerance in wheat plants (Abebe et al., 2003; Ramadan et al., 2013). The bacterial $m t l D$ gene can be 
transferred to plants by genetic engineering to induce the accumulation of mannitol in plant tissues. The expression of the mtlD gene in wheat (Triticum aestivum L.) plants results in the accumulation of mannitol and improved salt tolerance (Ramadan et al., 2013). This gene encodes the enzyme mannitol 1-phosphate dehydrogenase (EC 1.1.1.17), converting fructose 6-phosphate to mannitol 1-phosphate which in turn converts to mannitol (Bhauso et al., 2014).

Mannitol-accumulating gene $(m t l D)$ for salt stress tolerance enabled transgenic plants to improve their growth and yield under salinity stress (Abebe et al., 2003; Chunmei et al., 2010; Ramadan et al., 2013; Bhauso et al., 2014). Mannitol, a sugar alcohol, is considered as a cellular osmotic regulator (Ahdam, 1979). It can function as an intracellular osmolyte, and can protect plant cells from oxidative damage by scavenging toxic oxygen intermediates (Chaturvedi et al., 1997). In other biological systems, mannitol has been shown to serve as a compatible solute or osmoprotectant involved in stress tolerance. This indicates that mannitol accumulation functions in adaptation or tolerance to salinity stress.

Accumulations of carbohydrates such as sugar fractions (e.g., glucose, fructose, fructans and trehalose) and starch occur under salt stress (Tarkowski and Van den Ende, 2015). The major role played by these carbohydrates in stress mitigation involves osmoprotection, carbon storage, and scavenging of ROS. It was observed that salt stress increases the level of reducing sugars (sucrose and fructans) within the cell in a number of plants belonging to different species (Kerepesi and Galiba, 2000). Sucrose content was found to increase in tomato (Solanum lycopersicum) under salinity due to increased activity of sucrose phosphate synthase (Gao et al., 1998). Decrease in starch content and increase in reducing and non-reducing sugar contents were noted in leaves of Bruguiera parviflora (Tarkowski and Van den Ende, 2015).

The present study was designed with objective to evaluate the potential enhanced salt stress tolerance of transgenic wheat plants over-expressing $m t l D$. The study aimed to establish a relationship between changes in physio-chemical attributes and the degree of tolerance, in terms of improvement in plant growth, antioxidative defense system and yield. Growth traits, osmoprotectants, sugar fractions, mannitol, enzymatic and non-enzymatic antioxidants, nutritional status and yield and its quality of transgenic plants compared to those of non-transgenics were evaluated under salt stress $(85 \mathrm{mM} \mathrm{NaCl})$.

\section{Materials and Methods}

A 2-season (2009/2010 and 2010/2011) open greenhouse experiment was conducted in the Experimental Station of the Agricultural Research Center, Giza, Egypt using seeds of two wheat [Giza 163 (non-transgenic) and 235/3 (transgenic)] genotypes. The genotype 235/3 was produced from Giza 163 .

\subsection{Plant Expression Vector}

The genetic construct pAB4 (8.53 kb; Ramadan et al.,
2013), containing the E. coli $m t l D$ gene (encoding mannitol 1-phosphate dehydrogenase), was used as plant expression vector. The $m t l D$ gene was functioned under the control of maize ubiquitin ( $u b i)$ promoter (Christensen et al., 1992) and NOS terminator. The plasmid contains bar gene (encoding the phosphinothricin acetyltransferase) as a selectable marker for Basta herbicide resistance (De Block et al., 1987) driven by CaMV35S promoter, with maize Adh1 intron in the 5 'nontranslated region, and terminated by NOS terminator.

A number of intermediate construction steps were done in order to obtain the plasmid pAB4. The Pcab promoter of pcabMTLD plasmid was replaced by maize ubiquitin promoter $(P-u b i)$ and ubil intron of pAHC17 plasmid to obtain pAB3. HinDIII fragment of bar gene cassette (2.09 $\mathrm{kb}$ ), obtained from pAB1 (Ramadan et al., 2013), was integrated into the unique HinDIII site of pAB3 to obtain pAB4 $(8.53 \mathrm{~kb})$.

\subsection{Wheat Transformation}

Immature embryos were isolated from field grown bread wheat (Triticum aestivum L.) cv. Giza 163 and pre-cultured for 1 - 4 days in the dark on modified MS medium (Weeks et al., 1993). The protocol used for transforming wheat plants was performed according to Sivamani et al. (2000). Primary transformants were transferred to the biocontainment greenhouse of AGERI, ARC, Egypt and tested using leaf painting assay with a $0.1 \%$ aqueous solution of Glufosinate $200^{\text {TM }}$ (AgrEvo USA, NJ, USA) containing 20\% glufosinate ammonium.

\subsection{Molecular Analysis of Putative mtlD Transgenic}

Genomic DNA was extracted from one selected putative transgenic, resistant during leaf painting to the herbicide Basta, as well as the wild type control, using DNeasy ${ }^{\mathrm{TM}}$ Plant Mini kit (Qiagen Inc., cat. no. 69104). PCR was performed by the amplification of the partial-length bar (400 bp) and full-length $m t l D(1.08 \mathrm{~kb})$ genes using specific primers with the following sequences:

\section{bar-F 5`TACATCGAGACAAGCACGGT3`}

bar-R 5 'GTGCCCTTGACCGTACTGCA3' $m t l D-F$

\section{CGAGATCTAACAATGAAAGCATTACATTTTGGCGC3` $m t l D-\mathrm{R}$}

\section{5 'GGGATATCTTATTGCATTGCTTTATAAGCGG3`}

The reaction conditions were optimized and mixtures (50$\mu 1$ total volume) composed of dNTPs $(0.2 \mathrm{mM}), \mathrm{MgCl}_{2}(1.5$ $\mathrm{mM})$, 1x buffer, primer $(0.2 \mu \mathrm{M})$, DNA (100 ng) and Taq DNA polymerase (2 units). Amplification was carried out in a Hybaid PCR Express programmed for 40 cycles as follows: $94^{\circ} \mathrm{C} / 4 \mathrm{~min}$ for primary denaturation $(1$ cycle $) ; 94^{\circ} \mathrm{C} / 1 \mathrm{~min}$ for denaturation, $55^{\circ} \mathrm{C} / 1 \mathrm{~min}$ for annealing with bar gene and $58^{\circ} \mathrm{C} / 1.2 \mathrm{~min}$ for annealing with $m t l D$ gene, $72^{\circ} \mathrm{C} / 2 \mathrm{~min}$ for extension ( 38 cycles); $72^{\circ} \mathrm{C} / 8 \mathrm{~min}$ ( 1 cycle); $4^{\circ} \mathrm{C}$ (infinitive). Agarose (1.2\%) was used for resolving PCR products. A Lambda phage DNA/BstEII digest was used as a standard DNA $(8.45,7.24,6.37,5.69,4.82,4.32,3.68,2.32,1.93$, 
$1.37,1.26,0.70,0.12 \mathrm{~kb})$. The run was performed at $80 \mathrm{~V}$ in Bio-Rad submarine $(8 \mathrm{~cm} \mathrm{X} 12 \mathrm{~cm})$, and bands were detected on UV-transilluminator (Data not shown).

Genomic Southern analysis (Southern, 1975) was carried out for the selected T0 transgenic (Data not shown).

\subsection{Sowing and Growth Conditions}

The T3 and T4 grains, collected from progeny of the homozygous transgenic bread wheat (235/3) with the highest $m t l D$ gene expression, were utilized for two experiments in two consecutive seasons 2009/2010 and 2010/2011, respectively. Twenty seeds were sown on $20^{\text {th }}$ and on $18^{\text {th }}$ of November, 2009 and 2010, respectively in each plastic pot (20 cm diameter, $30 \mathrm{~cm}$ deep) filled with a sandy soil that had been washed with $\mathrm{HCl}$, then washed with deionized water to remove all remnants of the acid. Each experiment, in each season, was consisted of four treatments; two for transgenic wheat (one received non-saline nutrient solution and the other received saline nutrient solution) and two for non-transgenic wheat (one received non-saline nutrient solution and the other received saline nutrient solution). There were twenty four pots/replicates per treatment, showing 96 pots per experiment. Pots were arranged in a complete randomized block design. In the 2009/2010 season, the day/night duration averaged $12 / 12 \pm 1 \mathrm{~h}$, the daily temperatures averaged $21.3^{\circ} \pm 2.6^{\circ} \mathrm{C}$, and the daily relative humidity averaged $59.8 \pm 5.1 \%$. In addition, the day/night duration that averaged $12 / 12 \pm 1 \mathrm{~h}$, the daily temperatures that averaged $22.1^{\circ} \pm 2.8^{\circ} \mathrm{C}$, and the daily relative humidity which averaged $61 \pm 4.6 \%$ were for the 2010/2011 season. The light intensity of the natural sunlight was suitable for all stages of wheat throughout the season. Seedlings were irrigated with 0.5 -strength Hoagland's solution every 3 days throughout the duration of the experiments. The salt concentration above $85 \mathrm{mM} \mathrm{NaCl}$ was found to be most significant at inhibiting the growth of non-transgenic wheat seedlings (data not shown). Therefore, $85 \mathrm{mM} \mathrm{NaCl}$ was applied in the nutrient solution in two of the four treatments, beginning the sowing date, to study the response of the transgenic or non-transgenic wheat plants to a phytotoxic level of salinity. At $75 \mathrm{~d}$ after sowing in both experiments, plants $(n=6)$ were used for various evaluations, and yield and its quality were measured at the end of both experiments.

\subsection{Plant Growth Analysis and Yield Measurement}

At the end of tillering stage (Zadoks Code $=29), 6$ plants were removed from the pots of each treatment, along with the sand, and were dipped in a bucket filled with water. The plants were moved gently to remove all adhering sand particles. The number of leaves on each plant was counted. Leaf area was recorded using a digital leaf meter (LI-3000 Portable Area meter; LI-COR, Lincoln, NE, USA). The shoot and root of each plant were separated and the size of root system was measured using a graduated cylinder and water. The plant parts were then placed in an oven at $80^{\circ} \mathrm{C}$ for $24 \mathrm{~h}$ and the dry weight of shoots and roots were recorded. At ripening stage (Zadoks Code $=94)$, spikes were collected and counted and then their grains were extracted to measure 1000 -grain weight and grain weight per plant. The produced grains were used to estimate yield quality (grain starch, protein and soluble sugars).

\subsection{Determination of Leaf Chlorophylls, Ascorbic acid and Glutathione Concentrations}

The concentration of chlorophylls [in $\mathrm{mg} \mathrm{g}^{-1}$ fresh weight (FW)] was estimated using plants collected at the end of tillering stage according to Arnon (1949). Leaf discs (0.5 g FW) were homogenized in $50 \mathrm{ml}$ of $80 \%(\mathrm{v} / \mathrm{v})$ acetone and centrifuged at $3,000 \times g$ for $20 \mathrm{~min}$. The optical density of the acetone extract was measured at $663 \mathrm{~nm}, 645 \mathrm{~nm}$, and $470 \mathrm{~nm}$ using a UV-160A UV-Visible Recording Spectrometer (Shimadzu, Kyoto, Japan).

Using plants collected at the end of tillering stage, ascorbic acid (AsA) concentrations (in mg $100 \mathrm{~g}^{-1} \mathrm{FW}$ ) were determined using the 2,6-dichloro-indophenol method (Helrich, 1990). Frozen leaf samples (0.2 g FW) were pulverized in a domestic grinder (Magefesa, Madrid, Spain) and triplicate $10 \mathrm{~g}$ aliquots of each sample were immediately homogenized in $50 \mathrm{ml}$ of a $3 \%(\mathrm{w} / \mathrm{v})$ metaphosphoric acid plus $8 \%(\mathrm{v} / \mathrm{v})$ acetic acid solution. The extracts were centrifuged for $15 \mathrm{~min}$ at $7,000 \times g$, filtered through six layers of cheese-cloth, and made up to $100 \mathrm{ml}$ with the same metaphosphoric acid/acetic acid solution. Triplicate aliquots of each sample were titrated with a $250 \mathrm{mg}^{-1}$ 2,6-dichloroindophenol solution. AsA reduced the 2,6-dichloroindophenol to a colorless solution and a slight excess of unreduced dye, resulting in a characteristic light-pink color, indicated the end point of the reaction (Helrich, 1990).

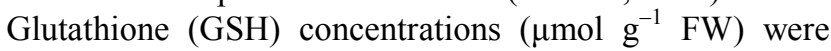
determined in plants collected at the end of tillering stage using the method described by Griffth (1980). Fresh, fullyexpanded leaf tissue $(50 \mathrm{mg})$ was homogenized in $2 \mathrm{ml}$ of $2 \%(\mathrm{v} / \mathrm{v})$ metaphosphoric acid and centrifuged at 17,000 $\times \mathrm{g}$ for $10 \mathrm{~min}$. The supernatant $(0.9 \mathrm{ml})$ was neutralized by adding $0.6 \mathrm{ml}$ of $10 \%(\mathrm{w} / \mathrm{v})$ sodium citrate. Each $1.0 \mathrm{ml}$ assay contained $700 \mu \mathrm{l}$ of $0.3 \mathrm{mM}$ NADPH, $100 \mu \mathrm{l}$ of $6 \mathrm{mM}$ 5,5'-dithio-bis-2-nitrobenzoic acid, $100 \mu \mathrm{l}$ distilled water, and $100 \mu \mathrm{l}$ of extract and it was stabilized at $25^{\circ} \mathrm{C}$ for $3-4 \mathrm{~min}$. Ten $\mu \mathrm{l}$ of $5 \mathrm{mg} \mathrm{ml}^{-1} \mathrm{GSH}$ reductase was added and the absorbance was recorded at $412 \mathrm{~nm}$. GSH concentrations were calculated from a standard curve.

\subsection{Determination of Shoot Concentrations of Free Proline and Total Soluble Sugars}

Free proline concentrations in dried shoots were measured using plants collected at the end of tillering stage by the method of Bates et al. (1973). Samples (0.5 g) were extracted by grinding in $10 \mathrm{ml}$ of $3 \%(\mathrm{v} / \mathrm{v})$ sulphosalicylic acid. The mixtures were then centrifuged at $10,000 \times \mathrm{g}$ for $10 \mathrm{~min}$. Two $\mathrm{ml}$ of freshly prepared acid-ninhydrin solution was added to $2 \mathrm{ml}$ of the supernatant in a test-tube. Tubes were incubated in a water bath at $90^{\circ} \mathrm{C}$ for $30 \mathrm{~min}$. The reaction 
was terminated in an ice-bath. The reaction mixtures were extracted with $5 \mathrm{ml}$ of toluene and vortex mixed for $15 \mathrm{~s}$. The tubes were allowed to stand for $\geq 20 \mathrm{~min}$ in the dark at room temperature to separate the toluene and aqueous phases. The toluene phases were then collected carefully into new testtubes and their absorbance were read at $520 \mathrm{~nm}$. The proline concentration was expressed as $\mathrm{mg} \mathrm{g}^{-1}$ dry sample using a standard curve. The standard curve was made using the pure amino acid proline at several concentrations (i.e., 0.001, 0.01, $0.1,0.2$ and $0.5 \mathrm{mg}$ ) with the same procedure conducted for plant samples.

Total soluble sugars (TSS) were extracted and determined in wheat shoots using plants collected at the end of tillering stage and harvested grains (at ripening stage) according to Irigoyen et al. (1992). A sample $(0.2 \mathrm{~g})$ of dried material was homogenized in $5 \mathrm{ml}$ of $96 \%(\mathrm{v} / \mathrm{v})$ ethanol and washed with $5 \mathrm{ml} \mathrm{70 \% (v/v)} \mathrm{ethanol.} \mathrm{The} \mathrm{extract} \mathrm{was} \mathrm{centrifuged} \mathrm{at} 3500$ $\times \mathrm{g}$ for $10 \mathrm{~min}$. The supernatant was then stored at $4{ }^{\circ} \mathrm{C}$ prior to measurement. TSS concentrations were determined by reacting $0.1 \mathrm{ml}$ of the ethanolic extract of each sample with 3 $\mathrm{ml}$ of freshly-prepared anthrone reagent (150 mg anthrone + $100 \mathrm{ml}$ of $72 \%$ (v/v) sulphuric acid) by placing it in a boiling water bath for $10 \mathrm{~min}$. After cooling, the absorbance of the mixtures was recorded at $625 \mathrm{~nm}$ using a Bausch and Lomb2000 Spectronic Spectrophotometer (Thermo Spectronic, Cambridge, UK).

\subsection{Determination of Shoot Concentrations of Sugar Alcohols and Soluble Sugar Fractions}

Using plants collected at the end of tillering stage, soluble sugars were extracted by mixing $100 \mathrm{mg}$ of dried shoots with $5 \mathrm{ml}$ ethanol $(80 \%)$ in screw-capped tubes for $1 \mathrm{~h}$ at $100^{\circ} \mathrm{C}$. The samples were centrifuged at $1000 \times g$ for $10 \mathrm{~min}$ at room temperature. The extraction was repeated three times and the supernatants were combined (Masuda et al., 1996). Soluble sugars were analyzed by using HP-5890 GC equipped with HP-5972 mass spectrometer. One $\mathrm{ml}$ of the soluble sugar extract was evaporated to dryness at $40^{\circ} \mathrm{C}$ under stream of nitrogen. Half $\mathrm{ml}$ of isopropanol (HPLC grade) was added to remove water residue, shaken gently and evaporated to dryness under a stream of nitrogen at $40^{\circ} \mathrm{C}$. The remaining residue was silylated as described by Kirk and Sawyer (1991). Then, $250 \mu \mathrm{l}$ of hydroxyl amine hydrochloride $(2.5 \%)$ in anhydrous pyridine were added and the reaction was incubated in an oven at $80^{\circ} \mathrm{C}$ for $30 \mathrm{~min}$. After cooling, $0.5 \mathrm{ml}$ of silylation reagent (trimethylchlorosilane [TMS], N, $\mathrm{N}-\mathrm{O}$ bis-[trimethylsilyl] acetamide, 1:5 v/v) was added and incubated in an oven at $80^{\circ} \mathrm{C}$ for $30 \mathrm{~min}$. The $\mathrm{GC}$ separation conditions were; inlet temperature $\left(250^{\circ} \mathrm{C}\right)$, mobile phase (helium), flow rate $\left(1 \mathrm{ml} \mathrm{min}^{-1}\right)$, oven temperature program (initial temperature $80^{\circ} \mathrm{C}, 10^{\circ} \mathrm{C} \mathrm{min}^{-1}$, up to $200^{\circ} \mathrm{C}$ for 10 min), HP-innowax column (30 $\mathrm{m} \times 0.25 \mathrm{~mm} \mathrm{ID)}$ and $\mathrm{MS}$ detector temperature $\left(300^{\circ} \mathrm{C}\right)$. The obtained mass spectra were analyzed by Wiley7N mass library. Individual and mixture of the trimethylchlorosilane (TMS) derivatives of standard monosaccharides and sugar alcohols (i.e., glucose, galactose, fructose, galacturonic acid, mannitol and sorbitol) were injected into the GC to ensure the retention time of each sugar.

\subsection{Determination of Enzymatic Activities}

The activity of $\alpha$-amylase was determined using plants collected at the end of tillering stage by the method of Petrova and Bolotina (1956). Half gram of fresh leaves of each treatment was homogenized in polytron with $4 \mathrm{ml}$ phosphate buffer $(\mathrm{pH}, 6.0)$. The extracts were centrifuged at $400 \mathrm{rpm}$ for $15 \mathrm{~min}$. The activity of $\alpha$-amylase was determined in the supernatant using Merck's soluble Lintner starch as a substrate and $0.1 \mathrm{ml}$ of the extract. Enzyme activity was expressed $\left(\Delta_{620} \mathrm{~min}^{-1} \mathrm{~g}^{-1} \mathrm{FW}\right)$ as changes in the optical density (OD) at $620 \mathrm{~nm}$.

Peroxidase activity was determined as outlined by Maehly and Chance (1954). Half gram of fresh leaves of each treatment was homogenized in polytron with $4 \mathrm{ml}$ phosphate buffer ( $\mathrm{pH}$ 6.0). The extracts were centrifuged at $400 \mathrm{rpm}$ for $15 \mathrm{~min}$. The enzyme activity was measured in the supernatant by using a reaction mixture consisting of $1.5 \mathrm{ml}$ of phosphate buffer, $1.5 \mathrm{ml}$ of $\mathrm{H}_{2} \mathrm{O}_{2}$ (20 volume), and $1.5 \mathrm{ml}$ of $0.04 \mathrm{M}$ catechol solution as a substrate and $0.1 \mathrm{ml}$ of the extract. Enzyme activity was expressed $\left(\Delta_{470} \mathrm{~min}^{-1} \mathrm{~g}^{-1} \mathrm{FW}\right)$ as changes in the OD at $470 \mathrm{~nm}$.

Catalase activity was determined by the method of Beer and Sizer (1952). Half gram of fresh leaves of each treatment was homogenized in polytron with $4 \mathrm{ml}$ phosphate buffer (pH 7.0). The extracts were centrifuged at $400 \mathrm{rpm}$ for 15 min. Catalase activity was measured in the supernatant using $1.9 \mathrm{ml}$ of reagent grade water, $1.0 \mathrm{ml}$ of $\mathrm{H}_{2} \mathrm{O}_{2}$ as a substrate and $0.1 \mathrm{ml}$ of extract. Enzyme activity was expressed $\left(\Delta_{240}\right.$ $\mathrm{min}^{-1} \mathrm{~g}^{-1} \mathrm{FW}$ ) as changes in the OD at $240 \mathrm{~nm}$.

Polyphenol oxidase activity was determined by the method described by Taneja and Sachar (1974). Half gram of fresh leaves of each treatment was homogenized in polytron with 4 $\mathrm{ml}$ phosphate buffer ( $\mathrm{pH}$ 6.0). The reaction mixture contained $2 \mathrm{ml}$ of $1 \%$ catechol solution as a substrate, $0.2 \mathrm{ml}$ of enzyme extract and rest of $0.05 \mathrm{M}$ sodium phosphate buffer ( $\mathrm{pH}$ 6.8) in a volume of $4 \mathrm{ml}$. Enzyme activity was expressed $\left(\Delta_{430}\right.$ $\min ^{-1} \mathrm{~g}^{-1} \mathrm{FW}$ ) as changes in the OD at $430 \mathrm{~nm}$.

Ascorbic acid oxidase activity was determined by the method mentioned by Dawson and Magee (1955). Half gram of fresh leaves of each treatment was homogenized in polytron with $4 \mathrm{ml}$ phosphate buffer ( $\mathrm{pH}$ 6.2). The sample cuvette contained $1.0 \mathrm{ml}$ of sodium phosphate buffer $(\mathrm{pH}$ 6.2), $0.2 \mathrm{ml}$ of ascorbic acid $\left(10^{-3} \mathrm{~mol}\right)$ as a substrate, $0.1 \mathrm{ml}$ of enzyme extract and $1.7 \mathrm{ml}$ of distilled water. Enzyme activity was expressed $\left(\Delta_{265} \mathrm{~min}^{-1} \mathrm{~g}^{-1} \mathrm{FW}\right)$ as changes in the OD at $265 \mathrm{~nm}$.

Superoxide dismutase activity was assayed by measuring its ability to inhibit the photochemical reduction of nitroblue tetrazolium (NBT) and the change in absorbance was measured at $560 \mathrm{~nm}$ (Beauchamp and Fridovich, 1971). The reaction mixture consisted of $25 \mathrm{mM}$ phosphate buffer $(\mathrm{pH}$ 7.8), $65 \mu \mathrm{M}$ NBT, $2 \mu \mathrm{M}$ riboflavin, enzyme extract, and TEMED and the reaction mixture was exposed to light of 350 $\mu \mathrm{mol} \mathrm{m} \mathrm{m}^{-2} \mathrm{~s}^{-1}$ for $15 \mathrm{~min}$. Enzyme activity was expressed as 
$\Delta_{560} \min ^{-1} \mathrm{~g}^{-1} \mathrm{FW}$ following the changes in the OD at 560 $\mathrm{nm}$.

\subsection{Determination of Macro- and micro-nutrients and Na Contents}

The contents of macro- and micro-nutrients and sodium were determined using plants collected at the end of tillering stage. Nitrogen contents were determined in wheat shoots and grains by the Ningbo Medical Instruments Co. (Ningbo, P. R. China) using a micro-Kjeldahl apparatus, as described by the A.O.A.C. (1995). P contents were measured in wheat shoots using the molybdenum-reduced molybdophosphoric blue colour method (Jackson, 1967) in sulphuric acid (with reduction to exclude arsenate). Sulphomolybdic acid (molybdenum blue), diluted sulphomolybdic acid, and 8\% $(\mathrm{w} / \mathrm{v})$ sodium bisulphite- $\mathrm{H}_{2} \mathrm{SO}_{4}$ were used as standard reagents. $\mathrm{K}^{+}$and $\mathrm{Na}^{+}$ion contents were measured in plant shoots using a Perkin-Elmer Model 52-A flame photometer (Glenbrook, Stamford, CT, USA) as described by Page et al. (1982). Ca, Mg, Fe, Mn and $\mathrm{Zn}$ contents was determined in wheat shoots using a Perkin-Elmer Model 3300 Atomic Absorption Spectrophotometer (Chapman and Pratt, 1961).

\subsection{Determination of Harvested Grain Quality}

At ripening stage, grains from each treatment were used to assess grain quality. Protein content in grains was measured by a Near Infrared Analyzer (Axiom Analytical, Inc., 1451A Edinger Ave, Tustin, CA 92780) (Granlund and Zimmerman, 1975). Starch contents of grains were determined as described by A.O.A.C. (1995). Starch was extracted by using ethanol $(80 \%)$, hydrolyzed by using concentrated $\mathrm{HCl}$, and was then determined by using Fehling
$(\mathrm{A}+\mathrm{B})$ reagent and methylene blue as an indicator. Total soluble sugars (TSS) were extracted and determined according to Irigoyen et al. (1992).

\section{Statistical Analysis}

All obtained data of the two seasons were statistically analyzed according to the technique of analysis of variance (ANOVA) for the complete randomized blocks design using means of "MSTAT-C" computer software package. Least Significant Difference (LSD) method was used to test the differences between treatment means at 5\% level of probability $(p \leq 0.05)$ as described (Snedecor and Cochran, 1990).

\section{Results}

\subsection{Growth Characteristics}

The data in Table 1 show that growing wheat plants in the presence of $\mathrm{NaCl}(85 \mathrm{mM})$ in nutrient solution significantly reduced all growth traits, measured as number of leaves and leaf area per plant, root system size and plant dry weights, of non-transgenic wheat plants (G 163), while it did not affect the growth parameters of $m t l D$ gene-gained transgenic plants (235/3) compared to unstressed plants in both 2009/2010 and $2010 / 2011$ seasons. The reductions in the growth traits of non-transgenic plants under salt stress were $4.5 \%, 19.7 \%$, $17.2 \%$, and $19.2 \%$ in the first season and were $12.9 \%, 19.7 \%$, $19.3 \%$, and $19.1 \%$ in the second season, respectively, compared to unstressed plants. However, the mtlD genecontained transgenic plants were observed to alleviate these deleterious effects of $\mathrm{NaCl}$-salinity.

Table 1. Effect of irrigation with NaCl-free nutrient solution (NS) or 85 mM-NaCl-containing nutrient solution (Saline-NS) on growth traits of both transgenic and non-transgenic wheat plants grown in two seasons.

\begin{tabular}{|c|c|c|c|c|c|c|c|}
\hline \multirow[b]{2}{*}{ Treatment } & \multirow[b]{2}{*}{ Genotype } & \multicolumn{6}{|l|}{ Parameters } \\
\hline & & $\begin{array}{l}\text { No. of leaves } \\
\text { plant }^{-1}\end{array}$ & $\begin{array}{l}\text { Leaf area } \\
\text { plant }^{-1}\left(\mathrm{~cm}^{2}\right)\end{array}$ & $\begin{array}{l}\text { Root system } \\
\text { size }\left(\mathrm{cm}^{3}\right)\end{array}$ & $\begin{array}{l}\text { Shoot DW } \\
\text { plant }^{-1} \text { (g) }\end{array}$ & $\begin{array}{l}\text { Root DW } \\
\text { plant }^{-1}(g)\end{array}$ & $\begin{array}{l}\text { Total DW } \\
\text { plant }^{-1}(\mathrm{~g})\end{array}$ \\
\hline \multicolumn{8}{|c|}{$2009 / 2010$ season } \\
\hline \multirow{2}{*}{ NS } & G 163 & $7.3 \pm 0.6 b^{\dagger}$ & $84.9 \pm 4.9 b$ & $5.8 \pm 0.3 b$ & $2.06 \pm 0.11 b$ & $1.28 \pm 0.09 b$ & $3.34 \pm 0.21 b$ \\
\hline & $235 / 3$ & $8.7 \pm 0.8 \mathrm{a}$ & $99.9 \pm 5.7 \mathrm{a}$ & $6.9 \pm 0.4 \mathrm{a}$ & $2.89 \pm 0.15 a$ & $1.89 \pm 0.14 \mathrm{a}$ & $4.78 \pm 0.28 \mathrm{a}$ \\
\hline \multirow{2}{*}{ Saline-NS } & G 163 & $7.0 \pm 0.6 \mathrm{c}$ & $68.2 \pm 3.4 \mathrm{c}$ & $4.8 \pm 0.3 c$ & $1.77 \pm 0.10 \mathrm{c}$ & $0.93 \pm 0.07 \mathrm{c}$ & $2.70 \pm 0.18 \mathrm{c}$ \\
\hline & $235 / 3$ & $8.3 \pm 0.7 a$ & $98.0 \pm 5.2 \mathrm{a}$ & $6.6 \pm 0.3 \mathrm{a}$ & $2.85 \pm 0.13 a$ & $1.86 \pm 0.12 \mathrm{a}$ & $4.71 \pm 0.24 \mathrm{a}$ \\
\hline \multicolumn{8}{|c|}{$2010 / 2011$ season } \\
\hline \multirow{2}{*}{ NS } & G 163 & $10.3 \pm 0.8 b$ & $102.7 \pm 6.1 b$ & $8.3 \pm 0.4 b$ & $2.49 \pm 0.12 b$ & $1.55 \pm 0.12 b$ & $4.04 \pm 0.25 b$ \\
\hline & $235 / 3$ & $13.7 \pm 1.1 \mathrm{a}$ & $120.9 \pm 6.8 \mathrm{a}$ & $9.9 \pm 0.5 a$ & $3.50 \pm 0.15 \mathrm{a}$ & $2.29 \pm 0.17 \mathrm{a}$ & $5.79 \pm 0.30 \mathrm{a}$ \\
\hline \multirow{2}{*}{ Saline-NS } & G 163 & $9.0 \pm 0.8 \mathrm{c}$ & $82.5 \pm 4.1 \mathrm{c}$ & $6.7 \pm 0.4 \mathrm{c}$ & $2.14 \pm 0.11 \mathrm{c}$ & $1.13 \pm 0.11 \mathrm{c}$ & $3.27 \pm 0.24 c$ \\
\hline & $235 / 3$ & $13.3 \pm 1.0 \mathrm{a}$ & $118.6 \pm 6.3 a$ & $9.5 \pm 0.4 \mathrm{a}$ & $3.45 \pm 0.13 a$ & $2.25 \pm 0.15 \mathrm{a}$ & $5.70 \pm 0.25 \mathrm{a}$ \\
\hline
\end{tabular}

${ }^{\dagger}$ Values are means $\pm \mathrm{SE}(\mathrm{n}=6)$. Mean values in each column followed by different lower-case letters are significantly different at $p \leq 0.05$.

\subsection{Leaf Chlorophylls}

The data shown in Table 2 reveal that total chlorophylls concentration in leaves of G 163 wheat plants were significantly reduced in the presence of $85 \mathrm{mM} \mathrm{NaCl}$ stress, but this of $m t l D$ transgenic plants was not affected compared to unstressed plants over two seasons. The reduction in chlorophylls concentration of non-transgenic plants under $\mathrm{NaCl}$ stress was $19.0 \%$ in the $2009 / 2010$ season and $13.7 \%$ in the $2010 / 2011$ season, respectively, compared to unstressed plants. In the presence of $85 \mathrm{mM} \mathrm{NaCl}, m t l D$ transgenic plants positively faced the adverse effects of salt stress, and 
maintained their chlorophyll values at the same levels as in unstressed plants.

Table 2. Effect of irrigation with NaCl-free nutrient solution (NS) or 85 mM-NaCl-containing nutrient solution (Saline-NS) on the concentrations of leaf chlorophylls $\left(\mathrm{mg} \mathrm{g}^{-1} \mathrm{FW}\right)$, and shoot free proline and total soluble sugars $\left(\mathrm{mg}^{-1} \mathrm{DW}\right)$ of both transgenic and non-transgenic wheat plants grown in two seasons.

\begin{tabular}{|c|c|c|c|c|}
\hline \multirow{2}{*}{ Treatment } & \multirow{2}{*}{ Genotype } & \multicolumn{3}{|l|}{ Parameters } \\
\hline & & Total chlorophylls & Free proline & Total soluble sugars \\
\hline \multicolumn{5}{|c|}{$2009 / 2010$ season } \\
\hline \multirow{2}{*}{ NS } & G 163 & $0.63 \pm 0.02 b^{\dagger}$ & $0.42 \pm 0.02 \mathrm{c}$ & $46.9 \pm 0.8 \mathrm{~d}$ \\
\hline & $235 / 3$ & $0.75 \pm 0.03 a$ & $0.52 \pm 0.03 b$ & $66.9 \pm 1.4 \mathrm{~b}$ \\
\hline \multirow{2}{*}{ Saline-NS } & G 163 & $0.51 \pm 0.02 \mathrm{c}$ & $0.49 \pm 0.03 b$ & $57.9 \pm 1.2 \mathrm{c}$ \\
\hline & $235 / 3$ & $0.74 \pm 0.03 a$ & $0.62 \pm 0.04 \mathrm{a}$ & $74.0 \pm 1.6 \mathrm{a}$ \\
\hline \multicolumn{5}{|c|}{$2010 / 2011$ season } \\
\hline NS & $235 / 3$ & $0.85 \pm 0.03 a$ & $0.44 \pm 0.03 b$ & $60.9 \pm 0.9 b$ \\
\hline \multirow{2}{*}{ Saline-NS } & G 163 & $0.63 \pm 0.02 \mathrm{c}$ & $0.43 \pm 0.03 b$ & $58.8 \pm 1.1 \mathrm{~b}$ \\
\hline & $235 / 3$ & $0.83 \pm 0.3 \mathrm{a}$ & $0.52 \pm 0.04 \mathrm{a}$ & $78.4 \pm 1.3 \mathrm{a}$ \\
\hline
\end{tabular}

${ }^{\dagger}$ Values are means \pm SE $(n=6)$. Mean values in each column followed by different lower-case letters are significantly different at $p \leq 0.05$.

\subsection{Concentrations of Free Proline, Total Soluble Sugars and Antioxidants}

The data in Tables 2 and 4 show that growing wheat plants in the presence of $\mathrm{NaCl}$ significantly increased the concentrations of free proline and total soluble sugars in both transgenic and non-transgenic plants compared to unstressed plants in both 2009/2010 and 2010/2011. However, the concentrations of ascorbic acid and glutathione were showed a reverse trend. They were significantly reduced in the presence of $\mathrm{NaCl}$ stress in non-transgenic plants, but those of $m t l D$ transgenic plants were not affected compared to unstressed plants in the first $(2009 / 2010)$ season. In the second $(2010 / 2011)$ season, they were not affected in both transgenic and non-transgenic plants in the presence of $\mathrm{NaCl}$.

\subsection{Concentrations of Mannitol and Sorbitol, and Soluble Sugar Fractions}

The data in Table 3 show that growing wheat plants in the presence of $85 \mathrm{mM} \mathrm{NaCl}$ significantly increased the concentrations of mannitol, fructose, glucose and galacturonic acid in both transgenic and non-transgenic plants compared to unstressed plants over both seasons. However, the concentrations of sorbitol and galactose were showed a reverse trend. They were significantly reduced in the presence of salt-stress in $m t l D$ transgenic plants, but were not affected in non-transgenic plants compared to unstressed plants in both seasons.

Table 3. Effect of irrigation with NaCl-free nutrient solution (NS) or 85 mM-NaCl-containing nutrient solution (Saline-NS) on the shoot concentrations of sugar alcohols mannitol and sorbitol, and soluble sugar fractions (mg $100 \mathrm{~g}^{-1} \mathrm{DW}$ ) of both transgenic and non-transgenic wheat plants grown in two seasons.

\begin{tabular}{|c|c|c|c|c|c|c|c|}
\hline \multirow{2}{*}{ Treatment } & \multirow{2}{*}{ Genotype } & \multicolumn{6}{|l|}{ Parameters } \\
\hline & & Mannitol & Sorbitol & Fructose & Glucose & Galactose & Galacturonic acid \\
\hline \multicolumn{8}{|c|}{$2009 / 2010$ season } \\
\hline \multirow{2}{*}{ NS } & G 163 & $15.2 \pm 0.1 \mathrm{~d}$ & $14.9 \pm 0.3 \mathrm{a}$ & $51.4 \pm 0.6 \mathrm{~d}$ & $81.3 \pm 0.9 \mathrm{~d}$ & $78.2 \pm 0.9 \mathrm{a}$ & $60.4 \pm 0.7 \mathrm{~d}$ \\
\hline & $235 / 3$ & $68.1 \pm 0.7 b$ & $9.9 \pm 0.1 b$ & $68.2 \pm 0.9 b$ & $98.9 \pm 1.2 b$ & $61.4 \pm 0.7 b$ & $78.8 \pm 0.8 b$ \\
\hline \multirow{2}{*}{ Saline-NS } & G 163 & $28.0 \pm 0.5 \mathrm{c}$ & $15.2 \pm 0.4 \mathrm{a}$ & $59.8 \pm 0.6 \mathrm{c}$ & $89.4 \pm 0.9 c$ & $79.5 \pm 0.9 \mathrm{a}$ & $68.7 \pm 0.7 \mathrm{c}$ \\
\hline & $235 / 3$ & $156.2 \pm 2.1 \mathrm{a}$ & $6.0 \pm 0.1 \mathrm{c}$ & $310.5 \pm 3.3 a$ & $524.6 \pm 6.1 \mathrm{a}$ & $41.3 \pm 0.4 \mathrm{c}$ & $104.6 \pm 1.1 \mathrm{a}$ \\
\hline \multicolumn{8}{|c|}{$2010 / 2011$ season } \\
\hline \multirow{2}{*}{ NS } & G 163 & $11.3 \pm 0.1 \mathrm{~d}$ & $15.7 \pm 0.2 \mathrm{a}$ & $53.3 \pm 0.6 \mathrm{~d}$ & $87.4 \pm 0.9 \mathrm{~d}$ & $75.5 \pm 0.8 \mathrm{a}$ & $64.0 \pm 0.6 \mathrm{~d}$ \\
\hline & $235 / 3$ & $76.0 \pm 0.9 b$ & $10.6 \pm 0.1 b$ & $71.4 \pm 0.8 b$ & $113.5 \pm 1.5 b$ & $62.9 \pm 0.6 \mathrm{~b}$ & $81.2 \pm 0.9 b$ \\
\hline \multirow{2}{*}{ Saline-NS } & G 163 & $16.0 \pm 0.2 \mathrm{c}$ & $14.5 \pm 0.3 \mathrm{a}$ & $59.7 \pm 0.5 c$ & $98.1 \pm 1.2 \mathrm{c}$ & $71.3 \pm 0.7 \mathrm{a}$ & $73.4 \pm 0.7 \mathrm{c}$ \\
\hline & $235 / 3$ & $176.1 \pm 2.8 \mathrm{a}$ & $8.2 \pm 0.1 \mathrm{c}$ & $309.8 \pm 3.1 \mathrm{a}$ & $493.5 \pm 4.8 \mathrm{a}$ & $32.7 \pm 0.3 c$ & $115.0 \pm 1.2 \mathrm{a}$ \\
\hline
\end{tabular}

${ }^{\dagger}$ Values are means \pm SE $(n=6)$. Mean values in each column followed by different lower-case letters are significantly different at $p \leq 0.05$.

\subsection{Antioxidative Enzyme Activities}

The activities of superoxide dismutase (SOD), peroxidase (POD), catalase (CAT), ascorbic acid oxidase (AAO), polyphenol oxidase (PPO) and $\alpha$-amylase in wheat plants were significantly increased with $\mathrm{NaCl}$ treatment in both transgenic and non-transgenic plants compared to unstressed both plants in both 2009/2010 and 2010/2011 seasons (Table 5 ). These increased activities of antioxidative enzymes were more pronounced in transgenic plants than non-transgenic plants. The increases in these enzyme activities in nontransgenic plants under salt stress were $25.0 \%, 11.8 \%$, $31.8 \%, 23.1 \%, 16.7 \%$ and $14.3 \%$, respectively in the first season, and were $26.7 \%, 23.1 \%, 26.3 \%, 18.8 \%, 33.3 \%$ and $20.8 \%$, respectively in the second season compared to unstressed plants. However, the increases in the activities of these enzymes in transgenic plants under $85 \mathrm{mM} \mathrm{NaCl}$ stress 
were $41.2 \%, 28.6 \%, 42.3 \%, 29.4 \%, 17.4 \%$ and $21.6 \%$, respectively in the first season, and were $50.0 \%, 40.0 \%$,
$28.6 \%, 19.0 \%, 37.0 \%$ and $29.0 \%$, respectively in the second season compared to unstressed plants.

Table 4. Effect of irrigation with NaCl-free nutrient solution (NS) or 85 mM-NaCl-containing nutrient solution (Saline-NS) on the leaf concentrations of

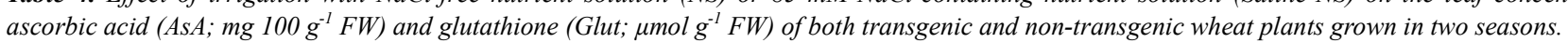

\begin{tabular}{ll|l|l}
\hline \multirow{2}{*}{ Treatment } & Genotype & Parameters & Glut. \\
\cline { 3 - 4 } $2009 / 2010$ season & & AsA & $129.2 \pm 4.2 \mathrm{~b}$ \\
NS & G 163 & $11.2 \pm 0.3 \mathrm{~b}$ & $159.2 \pm 5.3 \mathrm{a}$ \\
& $235 / 3$ & $16.5 \pm 0.4 \mathrm{a}$ & $100.7 \pm 3.4 \mathrm{c}$ \\
Saline-NS & G 163 & $8.7 \pm 0.2 \mathrm{c}$ & $166.3 \pm 5.1 \mathrm{a}$ \\
$2010 / 2011$ season & $235 / 3$ & $17.5 \pm 0.4 \mathrm{a}$ & $101.3 \pm 3.3 \mathrm{~b}$ \\
NS & & & $124.0 \pm 4.5 \mathrm{a}$ \\
& G 163 & $14.3 \pm 0.3 \mathrm{~b}$ & $100.0 \pm 3.4 \mathrm{~b}$ \\
Saline-NS & $235 / 3$ & $19.9 \pm 0.5 \mathrm{a}$ & $128.0 \pm 4.4 \mathrm{a}$ \\
\hline
\end{tabular}

${ }^{\dagger}$ Values are means \pm SE $(\mathrm{n}=6)$. Mean values in each column followed by different lower-case letters are significantly different at $p \leq 0.05$.

Table 5. Effect of irrigation with NaCl-free nutrient solution (NS) or $85 \mathrm{mM-NaCl-containing} \mathrm{nutrient} \mathrm{solution} \mathrm{(Saline-NS)} \mathrm{on} \mathrm{the} \mathrm{activity} \mathrm{of} \mathrm{some} \mathrm{enzymes}$ [superoxide dismutase (SOD; $\left.\Delta_{560} \mathrm{~min}^{-1} \mathrm{~g}^{-1} \mathrm{FW}\right)$, peroxidase $\left(P O D ; \Delta_{470} \mathrm{~min}^{-1} \mathrm{~g}^{-1} \mathrm{FW}\right)$, catalase $\left(\mathrm{CAT} ; \Delta_{240} \mathrm{~min}^{-1} \mathrm{~g}^{-1} \mathrm{FW}\right), \alpha$-amylase $\left(\Delta_{620} \mathrm{~min}^{-1} \mathrm{~g}^{-1} \mathrm{FW}\right)$, ascorbic acid oxidase ( $\left.A A O ; \Delta_{265} \mathrm{~min}^{-1} \mathrm{~g}^{-1} \mathrm{FW}\right)$ and polyphenol oxidase (PPO; $\left.\left.\Delta_{430} \mathrm{~min}^{-1} \mathrm{~g}^{-1} \mathrm{FW}\right)\right]$ of both transgenic and non-transgenic wheat plants grown in two seasons.

\begin{tabular}{|c|c|c|c|c|c|c|c|}
\hline \multirow{2}{*}{ Treatment } & \multirow{2}{*}{ Genotype } & \multicolumn{6}{|l|}{ Parameters } \\
\hline & & SOD & POD & CAT & $\alpha$-amylase & AAO & PPO \\
\hline \multicolumn{8}{|c|}{$2009 / 2010$ season } \\
\hline \multirow{2}{*}{ NS } & G 163 & $0.12 \pm 0.01 \mathrm{~d}^{\dagger}$ & $0.17 \pm 0.01 d$ & $0.22 \pm 0.01 \mathrm{c}$ & $0.28 \pm 0.01 \mathrm{c}$ & $0.13 \pm 0.01 \mathrm{c}$ & $0.18 \pm 0.01 \mathrm{~d}$ \\
\hline & $235 / 3$ & $0.17 \pm 0.01 \mathrm{~b}$ & $0.21 \pm 0.01 \mathrm{~b}$ & $0.26 \pm 0.02 b$ & $0.37 \pm 0.02 b$ & $0.17 \pm 0.01 b$ & $0.23 \pm 0.01 \mathrm{~b}$ \\
\hline \multirow{2}{*}{ Saline-NS } & G 163 & $0.15 \pm 0.01 \mathrm{c}$ & $0.19 \pm 0.01 \mathrm{c}$ & $0.29 \pm 0.02 b$ & $0.32 \pm 0.02 c$ & $0.16 \pm 0.01 b$ & $0.21 \pm 0.01 \mathrm{c}$ \\
\hline & $235 / 3$ & $0.24 \pm 0.02 \mathrm{a}$ & $0.27 \pm 0.02 \mathrm{a}$ & $0.37 \pm 0.03 a$ & $0.45 \pm 0.03 a$ & $0.22 \pm 0.01 \mathrm{a}$ & $0.27 \pm 0.02 \mathrm{a}$ \\
\hline \multicolumn{8}{|c|}{$2010 / 2011$ season } \\
\hline NS & $235 / 3$ & $0.20 \pm 0.01 \mathrm{~b}$ & $0.15 \pm 0.01 b$ & $0.28 \pm 0.02 b$ & $0.31 \pm 0.02 b$ & $0.21 \pm 0.01 b$ & $0.27 \pm 0.02 b$ \\
\hline \multirow{2}{*}{ Saline-NS } & G 163 & $0.19 \pm 0.01 b$ & $0.16 \pm 0.01 b$ & $0.24 \pm 0.02 c$ & $0.29 \pm 0.02 b$ & $0.19 \pm 0.01 \mathrm{c}$ & $0.28 \pm 0.02 b$ \\
\hline & $235 / 3$ & $0.30 \pm 0.02 \mathrm{a}$ & $0.21 \pm 0.01 \mathrm{a}$ & $0.36 \pm 0.03 a$ & $0.40 \pm 0.02 \mathrm{a}$ & $0.25 \pm 0.01 \mathrm{a}$ & $0.37 \pm 0.03 \mathrm{a}$ \\
\hline
\end{tabular}

${ }^{\dagger}$ Values are means $\pm \mathrm{SE}(\mathrm{n}=6)$. Mean values in each column followed by different lower-case letters are significantly different at $p \leq 0.05$.

Table 6. Effect of irrigation with NaCl-free nutrient solution (NS) or 85 mM-NaCl-containing nutrient solution (Saline-NS) on the contents of some shoot nutrients $(\% \mathrm{DW})$ of both transgenic and non-transgenic wheat plants grown in two seasons.

\begin{tabular}{|c|c|c|c|c|c|c|c|}
\hline \multirow{2}{*}{ Treatment } & \multirow{2}{*}{ Genotype } & \multicolumn{6}{|l|}{ Parameters } \\
\hline & & N\% & $\mathbf{P \%}$ & $\mathrm{Mg} \%$ & $\mathrm{Fe} \%$ & Mn\% & $\mathrm{Zn} \%$ \\
\hline \multicolumn{8}{|c|}{$2009 / 2010$ season } \\
\hline \multirow{2}{*}{ NS } & G 163 & $1.65 \pm 0.08 \mathrm{~b}^{\dagger}$ & $0.20 \pm 0.01 b$ & $0.32 \pm 0.02 b$ & $0.44 \pm 0.03 b$ & $0.26 \pm 0.02 b$ & $0.14 \pm 0.01 b$ \\
\hline & $235 / 3$ & $1.94 \pm 0.09 \mathrm{a}$ & $0.26 \pm 0.02 \mathrm{a}$ & $0.37 \pm 0.02 \mathrm{a}$ & $0.48 \pm 0.04 a$ & $0.30 \pm 0.02 \mathrm{a}$ & $0.19 \pm 0.02 \mathrm{a}$ \\
\hline \multirow{2}{*}{ Saline-NS } & G 163 & $1.45 \pm 0.07 \mathrm{c}$ & $0.17 \pm 0.01 \mathrm{c}$ & $0.26 \pm 0.01 \mathrm{c}$ & $0.35 \pm 0.03 c$ & $0.19 \pm 0.01 \mathrm{c}$ & $0.11 \pm 0.01 \mathrm{c}$ \\
\hline & $235 / 3$ & $1.94 \pm 0.08 \mathrm{a}$ & $0.25 \pm 0.01 \mathrm{a}$ & $0.37 \pm 0.02 \mathrm{a}$ & $0.50 \pm 0.04 a$ & $0.31 \pm 0.02 \mathrm{a}$ & $0.19 \pm 0.02 \mathrm{a}$ \\
\hline \multicolumn{8}{|c|}{$2010 / 2011$ season } \\
\hline NS & $235 / 3$ & $1.96 \pm 0.08 \mathrm{a}$ & $0.25 \pm 0.02 \mathrm{a}$ & $0.32 \pm 0.02 \mathrm{a}$ & $0.49 \pm 0.03 \mathrm{a}$ & $0.23 \pm 0.01 b$ & $0.16 \pm 0.01 \mathrm{a}$ \\
\hline \multirow{2}{*}{ Saline-NS } & G 163 & $1.58 \pm 0.07 \mathrm{c}$ & $0.18 \pm 0.01 \mathrm{c}$ & $0.24 \pm 0.01 \mathrm{c}$ & $0.35 \pm 0.02 \mathrm{c}$ & $0.17 \pm 0.01 d$ & $0.10 \pm 0.01 \mathrm{c}$ \\
\hline & $235 / 3$ & $1.85 \pm 0.08 \mathrm{ab}$ & $0.25 \pm 0.02 \mathrm{a}$ & $0.31 \pm 0.02 \mathrm{ab}$ & $0.49 \pm 0.03 a$ & $0.25 \pm 0.01 \mathrm{a}$ & $0.15 \pm 0.01 \mathrm{a}$ \\
\hline
\end{tabular}

${ }^{\dagger}$ Values are means \pm SE $(\mathrm{n}=6)$. Mean values in each column followed by different lower-case letters are significantly different at $p \leq 0.05$.

\subsection{Plant Nutritional Status}

The contents of $\mathrm{N}, \mathrm{P}, \mathrm{K}^{+}, \mathrm{Ca}, \mathrm{Mg}, \mathrm{Fe}, \mathrm{Mn}, \mathrm{Zn}$ and $\mathrm{Na}^{+}$and the ratios of $\mathrm{K}^{+} / \mathrm{Na}^{+}$and $\mathrm{Ca} / \mathrm{Na}^{+}$are shown in Tables 6 and 7 . The contents of $\mathrm{N}, \mathrm{P}, \mathrm{Ca}, \mathrm{Mg}, \mathrm{Fe}, \mathrm{Mn}$ and $\mathrm{Zn}$ in nontransgenic wheat plants were significantly decreased in the presence of $85 \mathrm{mM} \mathrm{NaCl}$ stress, but those in $m t l D$ transgenic plants were not affected compared to unstressed plants over two seasons; 2009/2010 and 2010/2011. On the other hand,
$\mathrm{K}^{+}$ion contents in non-transgenic wheat plants were significantly decreased in the presence of salt stress, but those in $m t l D$ transgenic plants were significantly increased compared to unstressed plants in both seasons. In contrast, $\mathrm{Na}^{+}$ion contents in non-transgenic wheat plants were significantly increased under $85 \mathrm{mM} \mathrm{NaCl}$ stress, but those in $m t l D$ transgenic plants were not affected compared to unstressed plants over two seasons. This was positively reflected in the ratios of $\mathrm{K}^{+} / \mathrm{Na}^{+}$and $\mathrm{Ca} / \mathrm{Na}^{+}$. The ratios of 
$\mathrm{K}^{+} / \mathrm{Na}^{+}$in non-transgenic wheat plants were significantly decreased in the presence of salt stress, but those in $m t l D$ transgenic plants were significantly increased compared to unstressed plants in both seasons. On the other hand, the ratios of $\mathrm{Ca} / \mathrm{Na}^{+}$in non-transgenic wheat plants were significantly decreased under $\mathrm{NaCl}$ stress, but those in $m t l D$ transgenic plants were not affected compared to unstressed plants over two seasons.

Table 7. Effect of irrigation with NaCl-free nutrient solution (NS) or 85 mM-NaCl-containing nutrient solution (Saline-NS) on the contents of some shoot nutrients and their relations with $\mathrm{Na}^{+}(\% \mathrm{DW})$ of both transgenic and non-transgenic wheat plants grown in two seasons.

\begin{tabular}{|c|c|c|c|c|c|c|}
\hline \multirow{2}{*}{ Treatment } & \multirow{2}{*}{ Genotype } & \multicolumn{5}{|l|}{ Parameters } \\
\hline & & $\mathbf{K}^{+} \%$ & $\mathrm{Ca}^{2+} \%$ & $\mathrm{Na}^{+} \%$ & $\mathrm{~K}^{+} / \mathrm{Na}^{+}$ratio & $\mathrm{Ca}^{2+} / \mathrm{Na}^{+}$ratio \\
\hline \multicolumn{7}{|c|}{$2009 / 2010$ season } \\
\hline \multirow{2}{*}{ NS } & G 163 & $2.11 \pm 0.09 b^{\dagger}$ & $0.57 \pm 0.02 b$ & $0.63 \pm 0.02 b$ & $3.35 \pm 0.11 \mathrm{c}$ & $0.90 \pm 0.03 b$ \\
\hline & $235 / 3$ & $2.27 \pm 0.11 \mathrm{~b}$ & $0.67 \pm 0.03 a$ & $0.58 \pm 0.02 \mathrm{c}$ & $3.91 \pm 0.12 b$ & $1.16 \pm 0.04 a$ \\
\hline \multirow{2}{*}{ Saline-NS } & G 163 & $1.84 \pm 0.08 \mathrm{c}$ & $0.47 \pm 0.02 \mathrm{c}$ & $0.76 \pm 0.03 a$ & $2.42 \pm 0.09 \mathrm{~d}$ & $0.62 \pm 0.02 \mathrm{c}$ \\
\hline & $235 / 3$ & $2.66 \pm 0.13 a$ & $0.67 \pm 0.03 a$ & $0.57 \pm 0.02 c$ & $4.67 \pm 0.13 a$ & $1.18 \pm 0.04 \mathrm{a}$ \\
\hline \multicolumn{7}{|c|}{$2010 / 2011$ season } \\
\hline NS & $235 / 3$ & $2.11 \pm 0.10 \mathrm{~b}$ & $0.61 \pm 0.02 \mathrm{a}$ & $0.53 \pm 0.02 \mathrm{c}$ & $3.98 \pm 0.12 b$ & $1.15 \pm 0.04 \mathrm{a}$ \\
\hline \multirow{2}{*}{ Saline-NS } & G 163 & $1.73 \pm 0.07 \mathrm{~d}$ & $0.42 \pm 0.02 \mathrm{c}$ & $0.71 \pm 0.03 a$ & $2.44 \pm 0.07 d$ & $0.59 \pm 0.02 c$ \\
\hline & $235 / 3$ & $2.34 \pm 0.11 \mathrm{a}$ & $0.60 \pm 0.02 \mathrm{a}$ & $0.53 \pm 0.02 \mathrm{c}$ & $4.42 \pm 0.13 \mathrm{a}$ & $1.13 \pm 0.04 \mathrm{a}$ \\
\hline
\end{tabular}

${ }^{\dagger}$ Values are means \pm SE $(\mathrm{n}=6)$. Mean values in each column followed by different lower-case letters are significantly different at $p \leq 0.05$.

\subsection{Grain Yield and Its Quality}

The grain yield components (number of spikes and grain weight per plant, and 1000-grain weight) and grain quality (the contents of starch, protein and total soluble sugars) are shown in Table 8. All grain yield components of non-transgenic wheat plants were significantly decreased under $85 \mathrm{mM} \mathrm{NaCl}$ stress, but those of $m t l D$ transgenic plants were not affected compared to unstressed plants in both seasons of 2009/2010 and 2010/2011. Similar trend was obtained for the contents of starch and protein over two seasons. On the other hand, the grain contents of total soluble sugars in non-transgenic wheat plants were significantly increased in the presence of salt stress, but those in $m t l D$ transgenic plants were not affected compared to unstressed plants in both seasons.

Table 8. Effect of irrigation with NaCl-free nutrient solution (NS) or 85 mM-NaCl-containing nutrient solution (Saline-NS) on yield components and yield quality of both transgenic and non-transgenic wheat plants grown in two seasons.

\begin{tabular}{|c|c|c|c|c|c|c|c|}
\hline \multirow{2}{*}{ Treatment } & \multirow{2}{*}{ Genotype } & \multicolumn{6}{|l|}{ Parameters } \\
\hline & & Spikes No. plant $^{-1}$ & 1000-grain weight (g) & Grain weight spike $^{-1}$ (g) & Starch & Protein & Soluble sugars \\
\hline \multicolumn{8}{|c|}{$2009 / 2010$ season } \\
\hline \multirow{2}{*}{ NS } & G 163 & $2.1 \pm 0.1 \mathrm{~b}^{\dagger}$ & $20.7 \pm 1.5 b$ & $0.50 \pm 0.03 b$ & $61.9 \pm 1.4 \mathrm{~b}$ & $8.16 \pm 0.21 b$ & $1.76 \pm 0.07 \mathrm{c}$ \\
\hline & $235 / 3$ & $3.7 \pm 0.2 \mathrm{a}$ & $23.9 \pm 1.7 \mathrm{a}$ & $0.68 \pm 0.04 a$ & $71.0 \pm 1.8 \mathrm{a}$ & $9.85 \pm 0.28 \mathrm{a}$ & $2.50 \pm 0.11 \mathrm{a}$ \\
\hline \multirow{2}{*}{ Saline-NS } & G 163 & $1.7 \pm 0.1 \mathrm{c}$ & $18.8 \pm 1.3 \mathrm{c}$ & $0.39 \pm 0.02 \mathrm{c}$ & $53.1 \pm 1.2 \mathrm{c}$ & $7.46 \pm 0.19 c$ & $1.98 \pm 0.09 \mathrm{~b}$ \\
\hline & $235 / 3$ & $3.6 \pm 0.2 \mathrm{a}$ & $23.7 \pm 1.6 \mathrm{a}$ & $0.67 \pm 0.04 a$ & $70.8 \pm 1.7 \mathrm{a}$ & $9.74 \pm 0.24 \mathrm{a}$ & $2.55 \pm 0.11 \mathrm{a}$ \\
\hline \multicolumn{8}{|c|}{ 2010/2011 season } \\
\hline NS & $235 / 3$ & $3.8 \pm 0.2 \mathrm{a}$ & $24.8 \pm 1.8 \mathrm{a}$ & $0.95 \pm 0.05 \mathrm{a}$ & $69.3 \pm 1.7 \mathrm{a}$ & $10.26 \pm 0.29 \mathrm{a}$ & $2.42 \pm 0.12 \mathrm{a}$ \\
\hline \multirow{2}{*}{ Saline-NS } & G 163 & $1.9 \pm 0.1 \mathrm{c}$ & $18.0 \pm 1.4 \mathrm{c}$ & $0.54 \pm 0.03 c$ & $52.2 \pm 1.1 \mathrm{c}$ & $7.35 \pm 0.18 \mathrm{c}$ & $2.04 \pm 0.09 b$ \\
\hline & $235 / 3$ & $3.7 \pm 0.2 \mathrm{a}$ & $24.7 \pm 1.7 \mathrm{a}$ & $0.95 \pm 0.05 a$ & $68.0 \pm 1.6 \mathrm{a}$ & $10.32 \pm 0.29 \mathrm{a}$ & $2.44 \pm 0.12 \mathrm{a}$ \\
\hline
\end{tabular}

${ }^{\dagger}$ Values are means $\pm \mathrm{SE}(\mathrm{n}=6)$. Mean values in each column followed by different lower-case letters are significantly different at $p \leq 0.05$.

\section{Discussion}

Wheat $m t l D$ transgenic genotype $(235 / 3)$ was evaluated for growth parameters and various biochemical attributes against salinity stress. Accumulation of mannitol in $m t l D$ genegained transgenic plants is expected to impart abiotic stress tolerance (Khare et al., 2010; Bhauso et al., 2014). In addition, $m t l D$ gene participates in increase of soluble sugar fractions (i.e., fructose, glucose and galactronic acid) in the transgenic plants compared to the non-transgenics (Table 3). Mannitol is a six-carbon, non-cyclic sugar-alcohol having a role in storage of energy, regulation of coenzymes and osmoregulation. It is naturally synthesized in many plant species, while is absent in wheat (Stoop et al., 1996). It is known to function as scavenger of reactive oxygen species (ROS), therefore, it overcomes the peroxidation of lipids and consequent cell damage (Stoop et al., 1996). It is synthesized by the action of NADPH-dependent mannitol 1-phosphate dehydrogenase from fructose 6-phosphate. When expressed in transgenic plants, a gene encoding mannitol 1-phosphate dehydrogenase $(m t l D)$ from Escherichia coli resulted in mannitol production and a salinity-tolerant phenotype (Thomas et al., 1996). It has been suggested that mannitol found to contribute to $30-40 \%$ of the change in osmotic potential in transgenic plants. Rather, the stress-tolerant phenotype is due to protection by mannitol against oxidation by hydroxyl radicals. Mannitol may have also a dual function in stress protection, both by facilitating osmotic adjustment and by supporting redox control (Rathinasabapathi, 2000). 
Sugar fractions (monosaccharides) not only function as substrates for energy production, but, together with hormones, form an integral part of the plant signaling network regulating stress and defense responses (Van den Ende and El-Esawe, 2014), as well as cell-cycle and celldivision programs (Bihmidine et al., 2013). In addition to indirect sugar signaling events, sugars have been proposed to play a direct role in ROS-scavenging mechanisms (Van den Ende and Valluru, 2009). In recent years, sugars have become more widely recognized as members of the non-enzymatic antioxidant family (Keunen et al., 2013; Peshev et al., 2013). Under stress, soluble sugars and sugar-like compounds (e.g. mannitol, sorbitol, etc.) may assist in osmotic adjustments as well as in membrane and protein stabilization (Amiard et al., 2003). Matros et al. (2015) suggest that higher concentrations of sugars may act as genuine ROS scavengers in plants, contributing to cellular ROS homeostasis and membrane protection. It is speculated that like mannitol, fructans work in connection with either glutathione-ascorbate cycle or cell signaling pathways during stress (Shen et al., 1997).

In the present study, under salt-stress ( $85 \mathrm{mM} \mathrm{NaCl})$, a high increase in concentration of mannitol and soluble sugar fractions (i.e., fructose, glucose and galactronic acid) in transgenic genotypes was observed (Table 3). Thus, the increase in mannitol and soluble sugars content with increasing salt stress in transgenic plants indicates the saltstress tolerance capacity as reported by Bhauso et al. (2014) and Matros et al. (2015). Various transgenic plant species accumulating varying levels of mannitol and soluble sugars in their tissues have been shown to be tolerant to different abiotic stress types, including salinity (Abebe et al., 2003; Khare et al., 2010; Bhauso et al., 2014; Van den Ende and ElEsawe, 2014), assuring that the levels of mannitol and soluble sugar fractions synthesized and accumulated in the transgenic tissues were abundant enough to impart osmoprotection via compatible solute mechanism. Accompanied with the accumulation of mannitol in transgenic plants, the concentrations of fructose, glucose and galacturonic acid found to increase, but sorbitol and galactose concentrations were decreased (Table 3). Fructose increased as a result of conversion of mannitol and/or sorbitol to fructose. Sorbitol can also be directly converted to glucose. This might explain the decrease of sorbitol in transgenic plants as glucose is still produced by the conversion of fructose. Increase in the soluble sugar fractions (monosaccharides) of the transgenic plants may be resulted in the decrease in carbohydrates; polysaccharides (Ramadan et al., 2013). This is supported by the accumulation of galacturonic acid (Table 3), the building unit of pectin, and glucose, the building unit of cellulose, in the transgenic plants. Pectin and cellulose are the main polysaccharides, which are the first defense system towards plant pathogens.

Abebe et al. (2003) suggested that the performance of mannitol-accumulating transgenic plants is improved because of the scavenging of ROS, rather than osmoregulatory effects, as the plant did not accumulate sufficient mannitol to sustain the osmotic potential. The results of the present study indicate that the increased concentrations of glucose and fructose provide energy necessary for the plant to cope with salt-stress conditions. Chiang et al. (2005) indicated that fructose, glucose and sucrose are important substrates in plant metabolism to enhance tolerance of the high mannitolcontaining plants to salt-stress. So, it is worthwhile to measure other soluble sugar fractions under salt stress in order to get a better picture on the indirect effect of the transgene as well as the environmental condition on the levels of indigenously expressed soluble sugar fractions in wheat. Results of this study suggest that mannitol and soluble sugars play a major role in increasing salt tolerance by their functions as an osmolyte and their role in oxidative stress protection through increasing the plant content of $\mathrm{K}^{+}$ions (Table 7). Potassium in its ionic state is considered as an osmolyte that competes with $\mathrm{Na}^{+}$ions. In addition, increase in the concentrations of total soluble sugars and proline (Table 2) act as osmoprotectants and ROS scavengers (Matros et al., 2015). Proline is known to be associated with several functions such as stabilization of proteins and membranes (Mansour, 1998), C and $\mathrm{N}$ reserves for growth after stress relief (Hayashi et al., 2000), regulation of cytosolic acidity (Sivkumar et al., 2000), osmo-protection (Kishor et al., 2005), and antioxidation (Hoque et al., 2007). The increased concentrations of total soluble sugars in $m t l D$ transgenic genotype under salt stress maintain the cells turgor that leads to maintenance of metabolic activities in plant cells and/or to protect cells against oxidative damage, which directly correlated with the increased activity of the antioxidant system (enzymatic and non-enzymatic antioxidants; Tables 4 and 5). The accumulation of such compatible osmolytes involved in osmoregulation allows additional water to be taken up from the environment, thus buffering the immediate effect of salt-induced water shortage within the plant (Nanjo et al., 1999). Thus, accumulation of proline and soluble sugars is considered as an indicator for stress, and $m t l D$ transgenic wheat genotype responded with higher proline and soluble sugars accumulation, which probably resulted in tolerance of transgenic wheat genotype for salt stress. Hu et al. (2005) pointed out that the transgenic plants were better able than wild-type plants to maintain cell membrane integrity under salt stress, which supports the hypothesis that proline, mannitol and soluble sugars serve as a protective function.

Plant growth of the transgenic genotype (235/3) was found to significantly improve over the non-transgenic genotype (G 163 ) at the salinity level of $85 \mathrm{mM} \mathrm{NaCl}$ (Table 1). The superiority of the transgenic genotype (235/3) in biomass production may be attributed to that this genotype was collected more concentrations of osmoprotectants, mannitol and antioxidants and more activities of antioxidant enzymes than the non-transgenic genotype (Tables $2-5$ ). The improved growth of the $m t l D$ gene-contained transgenic wheat genotype plants can be explained also on the basis of the bacterial, E. coli, mtlD gene-accumulating mannitol and soluble sugars (Ramadan et al., 2013). Although mannitol and sugars play an important role in osmotic adjustment, they 
act as antioxidants to scavenge of $\mathrm{OH}^{-}$(Shen et al., 1997; Srivastava et al., 2010). The transgenic plants exhibited counteractive effect against the deleterious effects of $85 \mathrm{mM}$ $\mathrm{NaCl}$-salinity and had the capability to stimulate their growth with more osmolytes (i.e., free proline, soluble sugar fractions, and mannitol; Tables 2 and 3) and antioxidants (ascorbic acid and glutathione; Table 4). The transgenic wheat genotype over-expressing mannitol was able to maintain higher chlorophyll content under salt stress probably due to its ability to enhance its nutritional status (Tables 6 and 7), and proline and sugar concentrations, lowering the level of ROS and alleviating salt-stress induced enhancement in ribulose oxygenase activity (Husaini and Abdin, 2008; Matros et al., 2015).

Besides the increased concentrations of mannitol and sugars, the increased concentrations of antioxidants; ascorbic acid and glutathione in $m t l D$ transgenic wheat plants under $\mathrm{NaCl}$ stress (Table 4) alleviated the harmful effects of ROS generated by $\mathrm{NaCl}$-salinity stress. Ascorbic acid has been implicated in several types of biological activities in plants as an enzyme cofactor, as an antioxidant and as a donor/acceptor in electron transport at the plasma membrane or in the chloroplasts, all of which are related to oxidative stress resistance (Conklin, 2001). In addition, glutathione can act as an antioxidant in many ways. It can function directly as a ROS scavenger (Noctor and Foyer, 1998), stabilize membrane structure by removing acyl peroxides formed by lipid peroxidation reactions and recycle, as a reducing agent, ascorbic acid from its oxidized to its reduced form by the enzyme dehydroascorbate reductase (Loewus, 1988). The increase in the reduced glutathione content in transgenic plants as recorded in Table (4) may be due to the role of the enzymes ascorbate peroxidase, glutathione reductase (GR) and superoxide dismutase (SOD) which involved in the regeneration of glutathione and ascorbate that are important in the detoxification of ROS (Foyer et al., 1994). It could be concluded that ascorbic acid and glutathione can help, with mannitol and sugars, to alleviate the harmful effects of ROS by inhibiting the lipid peroxidation, involving in both electron transport of PS II and antioxidizing the system of chloroplasts (Thomas et al., 1992), reacting with peroxyl radicals, scavenging cytotoxic $\mathrm{H}_{2} \mathrm{O}_{2}$ and reacting non-enzymatically with other ROS (Sairam and Srivastava, 2002).

The increased activities of antioxidative enzymes; SOD, peroxidase (POD), catalase (CAT), ascorbic acid oxidase (AAO) and polyphenol oxidase (PPO) in $m t l D$ transgenic wheat plants (Table 5) alleviated the deleterious effects of ROS generated by salt-stress. In addition, a-amylase decomposes starch to increase simple soluble sugars (Table 2) for osmotic adjustment and ROS scavenging under stress. Salt-stressed transgenic plants; the genotype 235/3 showed higher activities of SOD, POD, CAT, AAO, PPO and $\alpha$ amylase than the non-transgenic genotype (G 163) under saltstress. This lead to hypothesize that the transferred gene $m t l D$ upregulates the SOD, POD, CAT, AAO, PPO and $\alpha$-amylase activities in transgenic wheat plants under salt-stress, establishing an efficient antioxidative defense mechanism to detoxify and scavenge the toxic ROS through an adoptive mechanism involving upregulation of these antioxidative enzymes.

The salt tolerance trait in natural wheat genotypes and many other monocot species is often closely associated with a low level of $\mathrm{Na}^{+}$ion accumulation in leaves with a high ratio of leaf $\mathrm{K}^{+} / \mathrm{Na}^{+}$(Schachtman and Munns, 1992). A comparative analysis on $\mathrm{Na}^{+}$and $\mathrm{K}^{+}$accumulation was performed, in this study, and revealed that $m t l D$ transgenic wheat plants under 85 $\mathrm{mM} \mathrm{NaCl}$-salinity accumulated significantly less contents of $\mathrm{Na}^{+}$and high contents of other essential elements including $\mathrm{K}^{+}$ than those in non-transgenic plants. This may be attributed to the increased levels of $\mathrm{K}^{+}$and $\mathrm{Ca}^{2+}$ which compete with $\mathrm{Na}^{+}$, and the role of osmolytes in diluting the toxic effects of $\mathrm{Na}^{+}$on plants in a possible manner.

The $m t l D$ transgenic wheat lines exhibited improved grain yield and its components of plants from saline soils. This provides direct evidence on usefulness of mannitol and sugar accumulation technology (Table 3) for increasing salttolerance of transgenic plants. Results herein showed that the transformation with bacterial $m t l D$ gene for mannitol and sugar accumulation minimizes the negative impacts of $\mathrm{NaCl}$ stress at $85 \mathrm{mM}$ with evidence of enhancing plant proline, $\mathrm{K}^{+}$ ions and antioxidant enzymes that support stressed plants to grow well and maximize their productivity. It is highly recommended that transgenic progeny is tested in the field under salt stress using enough number of genotypes and replications to get a better figure from statistical analysis.

Mannitol and sugar protective effects as compatible solutes may be sufficient to give marginal growth advantage observed in transformed plants. Biosynthesis and accumulation of mannitol and sugars in plants are correlated with salt-stress tolerance of plants (Su et al., 1999; Matros et al., 2015). These solutes are believed to function as protectors or stabilizers of enzymes or membrane structures that are sensitive to dehydrations or ionically induced damage. Therefore, transforming the mannitol-accumulating $m t l D$ gene to generate wheat genotypes to face the increasing abiotic stresses, including salinity is important and required. The best performing $m t l D$ transgenics could be incorporated in a breeding program to accumulate transgenes for stress tolerance in elite wheat genotypes in a step to commercialize these transgenics with the proper level of salt tolerance.

\section{References}

[1] Abebe, T., B. Guenzi, V. Martin, and J. Cushman. 2003. Tolerance of mannitol-accumulating transgenic wheat to water stress and salinity. Plant Physiol. 131:1748-1755.

[2] Ahdam, I., F. Larher, and G.R. Stewart. 1979. Sorbitol, a compatible osmotic solute in Plantago maritime. New Phytol. 82:671-678.

[3] Amiard, V., A. Morvan-Bertrand, J. P. Billard, C. Huault, F. Keller, and M. P. Prud'homme. 2003. Fructans, but not the sucrosyl-galactosides, raffinose and loliose, are affected by drought stress in perennial ryegrass. Plant Physiol. 132:22182229 . 
[4] A. O. A. C. 1995. Official Methods of Analysis. $16^{\text {th }}$ Edition. Association of Official Analytical Chemists, Washington, DC, USA.

[5] Arnon, D. I. 1949. Copper enzymes in isolated chloroplasts. Polyphenol-oxidase in Beta vulgaris L. Plant Physiol. 24:1-5.

[6] Askari, A., A. Pepoyan, and A. Parsaeimehr. 2012. Salt tolerance of genetic modified potato (Solanum tuberosum) cv. Agria by expression of a bacterial $m t l D$ gene. Adv. Agric. Bot. $4: 10-16$.

[7] Bates, L. S., R. P. Waldeen, and I. D. Teare. 1973. Rapid determination of free proline for water stress studies. Plant Soil. 39:205-207.

[8] Beauchamp, C., and I. Fridovich. 1971. Superoxide dismutase: Improved assays and an assay applicable to acrylamide gels. Anal. Biochem. 44:276-287.

[9] Beers, R. F., and I. W. Sizer. 1952. A spectrophotometric method for measuring the breakdown of hydrogen peroxide by catalase. J. Biol. Chem. 195:133-140.

[10] Bhauso, D. T. 2012. Transformation and characterization of transgenic groundnut (Arachis hypogaea L.) with mtlD gene for abiotic stress tolerance. Ph.D., Juangadh Agricultural University, Junagadh-362001, Gujarat, India.

[11] Bhauso, T. D., R. Thankappan, A. Kumar, G. P. Mishra, J. R. Dobaria, and M. V. Rajam. 2014. Over-expression of bacterial $m t l D$ gene confers enhanced tolerance to salt-stress and waterdeficit stress in transgenic peanut (Arachis hypogaea) through accumulation of mannitol. Aust. J. Crop Sci. 8:413-421.

[12] Bihmidine, S., C. T. Hunter, C. E. Johns, K. E. Koch, and D. M. Braun. 2013. Regulation of assimilate import into sink organs: update on molecular drivers of sink strength. Front. Plant Sci. 4:4-177.

[13] Chapman, H. D., and P.F. Pratt. 1961. Methods of Analysis for Soil, Plants and Water. University of California, Division of Agricultural Science, Berkeley, CA, USA, pp. 56-63.

[14] Chaturvedi, V., A. Bartiss, and B. Wong. 1997. Expression of bacterial $m t l D$ in Saccharomyces cerevisiae results in mannitol synthesis and protects a glycerol-defective mutant from highsalt and oxidative stress. J. Bacteriol. 179:157-162.

[15] Chiang, Y. J., C. Stushnoff, and A. E. McSay. 2005. Overexpression of mannitol-1-phosphate dehydrogenase increase mannitol accumulation and adds protection against chilling injury in petunia. J. Amer. Soc. Hortic. Sci. 130:605610 .

[16] Christensen, A. H., R. A. Sharrock, and P. H. Quail. 1992. Maize polyubiquitin genes: structure, thermal perturbation of expression and transcript splicing, and promoter activity following transfer to protoplasts by electroporation. Plant Molec. Biol. 18:675-689.

[17] Chunmei, H., Y. Aifang, Z. Weiwei, G. Qiang, and Z. Juren. 2010. Improved salt tolerance of transgenic wheat by introducing betA gene for glycine betaine synthesis. Plant Cell Tiss. Org. Cult. 101:65-78.

[18] Conklin, P. L. 2001. Recent advances in the role and biosynthesis of ascorbic acid in plants. Plant Cell Environ. 24:383-394.

[19] Dawson, C. R., and R. J. Magee. 1955. Ascorbic acid oxidase. In: Methods in Enzymology (Colowich, S.P., Kaplan, N.O., eds.), vol. 2, pp. 831-835, Academic press, New York, USA.

[20] Foyer, C. H., M. Lelandais, and K.J. Kunert. 1994. Photooxidative stress in plants. Physiol. Plant. 92:696-717.

[21] Galvani, A. 2007. The challenge of the food sufficiency through salt tolerant crops. Rev. Environ. Sci. Bio/Technol. $6: 3-16$.

[22] Gao, Z., M. Sagi, and S. H. Lips. 1998. Carbohydrate metabolism in leaves and assimilate partitioning in fruits of tomato (Lycopersicon esculentumL.) as affected by salinity. Plant Sci. 135(2):149-159.

[23] Granlund, M., and D. C. Zimmerman. 1975. Oil content of sunflower seed as determined by wide line Nuclear Megnetic Reasonance. Acad. Sci. 27:123-133.

[24] Griffth, O. W. 1980. Determination of glutathione and glutathione disulfide using glutathione reductase and 2 vinyl pyridine. Anal. Biochem. 106:207-212.

[25] Hayashi, F., T. Ichino, M. Osanai, and K. Wada. 2000. Oscillation and regulation of proline content by P5CS and ProDH gene expressions in the light/dark cycles in Arabidopsis thaliana L. Plant Cell Physiol. 41:1096-1101.

[26] Helrich, K. 1990. Official Methods of Analysis. Vitamin C (Ascorbic Acid). 15 ${ }^{\text {th }}$ Edition. The Association of Official Analytical Chemists, Benjamin Franklin Station, Washington, DC, USA. pp. 1058-1059.

[27] Hoque, M. A., M. N. Banu, E. Okuma, K. Amako, Y. Nakamura, Y. Shimoishi, and Y. Murata. 2007. Exogenous proline and glycinebetaine increase $\mathrm{NaCl}$-induced ascorbateglutathione cycle enzyme activities, and proline improves salt tolerance more than glycinebetaine in tobacco Bright Yellow2 suspension-cultured cells. J. Plant Physiol. 164:1457-1468.

[28] Hu, L., H. Lu, Q. Liu, X. Cheni, and X. Jiang. 2005. Overexpression of $m t l D$ gene in transgenic Populus tomentosa improves salt tolerance through accumulation of mannitol. Tree Physiol. 25:1273-1281.

[29] Husaini, A. M., and M. Z. Abdin. 2008. Overexpression of tobacco osmotin gene leads to salt stress tolerance in strawberry (Fragaria $\times$ ananassa Duch.) plants. Ind. J. Biotechnol. 7:465-471.

[30] Irigoyen, J.J., D.W. Emerich, and M. Sanchez-Diaz. 1992. Water stress induced changes in the concentrations of proline and total soluble sugars in nodulated alfalfa (Medicago sativa) plants. Physiol. Plant. 8:455-460.

[31] Jackson, M. L. 1967. Soil Chemical Analysis. Prentice Hall of India Pvt. Ltd., New Delhi, India, pp. 144-197; 326-338.

[32] Kerepesi, I., and G. Galiba. 2000. Osmotic and salt stressinduced alteration in soluble carbohydrate content in wheat seedlings. Crop Sci. 40(2):482-487.

[33] Keunen, E., D. Peshev, J. Vangronsveld, W. Van den Ende, and A. Cuypers. 2013. Plant sugars are crucial players in the oxidative challenge during abiotic stress: extending the traditional concept. Plant Cell Environ. 36:1242-1255.

[34] Khare, N., D. Goyary, N.K. Singh, P. Shah, M. Rathore, S. Anandhan, D. Sharma, M. Arif, and Z. Ahmed. 2010. Transgenic tomato cv. Pusa Uphar expressing a bacterial mannitol-1-phosphate dehydrogenase gene confers abiotic stress tolerance. Plant Cell Tiss. Org. Cult. 103:267-277. 
[35] Kirk, R.S., and R. Sawyer. 1991. Composition and analysis of foods. 9th Edition, Longman Scientific Technical, pp. 182-235.

[36] Kishor, P. B. K., Z. Hong, G. H. Miao, C. A. A. Hu, and D. P. S. Verma. 2005. Over production of 11-pyrroline-5carboxylate synthetase increases proline production and confers osmotolerance in transgenic plants. Plant Physiol. 108:1387-1394.

[37] Loewus, F. A. 1988. Ascorbic acid and its metabolic products. In: The biochemistry of plants (Preiss, J., ed.). Vol. 14. New York: Academic Press, pp. 85-107.

[38] Maehly, A. C., and B. C. Chance. 1954. The assay of catalases and peroxidases. In: Methods of Biochemical Analysis (Glick, D., Ed.). Vol. 1, Interscience Publish. New York.

[39] Mansour, M.M.F. 1998. Protection of plasma membrane of onion epidermal cells by glycinebetaine and proline against $\mathrm{NaCl}$ stress. Plant Physiol. Biochem. 36:767-772.

[40] Masuda, R., K. Kaneko, and I. Yamashita. 1996. Sugar and cyclitol determination in vegetables by HPLC using postcolumn fluorescent derivatization. J. Food Sci. 61:1186-1190.

[41] Matros, A., D. Peshev, M. Peukert, H.-P. Mock, and W. V. Ende. 2015. Sugars as hydroxyl radical scavengers: proof-ofconcept by studying the fate of sucralose in Arabidopsis. Plant J. 82:822-839.

[42] Munns, R., and M. Tester. 2008. Mechanisms of salinity tolerance. Ann. Rev. Plant Biol. 59:651-681.

[43] Nanjo, T., M. Kobayashi, Y. Yoshiba, Y. Sanada, K. Wada, H. Tsukaya, Y. Kakubari, K. Yanaguchi-Shinozaki, and K. Shinozaki. 1999. Biological functions of proline in morphogenesis and osmotolerance revealed in antisense transgenic Arabidopsis thaliana. Plant J. 18:185-193.

[44] Noctor, G., and C. H. Foyer. 1998. Ascorbate and glutathione: Keeping active oxygen under control. Ann. Rev. Plant Physiol. Plant Molec. Biol. 49:249-279.

[45] Page, A. I., R. H. Miller, and D. R. Keeny. 1982. Methods of Soil Analysis. Part II. Chemical and Microbiological Methods. 2nd. Edition. Amer. Soc. Agron. Mad., WI, USA, pp. 225-246.

[46] Peshev, D., R. Vergauwen, A. Moglia, E. Hideg, and W. Van den Ende. 2013. Towards understanding vacuolar antioxidant mechanisms: a role for fructans? J. Exp. Bot. 64:1025-1038.

[47] Petrova, A. N., and T. T. Bolotina. 1956. Studies on the enzyme of starch metabolism in potato tubers during growth. Biochem. 21:4-15.

[48] Pitman, M.G., and A. Lauchli. 2002. Global impact of salinity and agricultural ecosystems. In: Salinity: Environment Plants - Molecules (Lauchli, A., Luttge, U., Eds.), pp. 3-20, Kluer, Netherland: Dordrecht.

[49] Ramadan, A. M., H. F. Eissa, S. E. Hassanein, A. Z. Abdel Azeiz, O.M. Saleh, H.T. Mahfouz, F.M. El-Domyati, M. A. Madkour, and A. Bahieldin. 2013. Increased salt stress tolerance and modified sugar content of bread wheat stably expressing the $m t l D$ gene. Life Sci. J. 10:2348-2362.

[50] Rathinasabapathi, B. 2000. Metabolic engineering for stress tolerance: Installing osmoprotectant synthesis pathways-a review. Ann. Bot. 86:709-716.
[51] Sairam, R. K., and G. C. Srivastava. 2002. Changes in antioxidant activity in sub-cellular fractions of tolerant and susceptible wheat genotypes in response to long term salt stress. Plant Sci. 162:897-904.

[52] Sanchez, D. H., F. Lippold, H. Redestig, M. Hannah, A. Erban et al. 2008. Integrative functional genomics of salt acclimatization in the model legume Lotus japonicus. Plant J. 53, 973-987.

[53] Schachtman, D. P., and R. Munns. 1992. Sodium accumulation in leaves of Triticum species that differ in salt tolerance. Aust. J. Plant physiol. 19:331-340.

[54] Shen, B., R. G. Jensen, and H. J. Bohnert. 1997. Increased resistance to oxidative stress in transgenic plants by targeting mannitol biosynthesis to chloroplasts. Plant Physiol. 113:1177-1183.

[55] Sivamani, E., A. Bahieldin, J. M. Wraith, T. Al-Niemi, W. E. Dyer, T. D. Ho, and R. Qu. 2000. Improved biomass productivity and water use efficiency under water deficit conditions in transgenic wheat constitutively expressing the barley HVA1 gene. Plant Sci. 155:1-9.

[56] Sivkumar, P., P. Sharmila, and P. Pardha-Saradhi. 2000. Proline alleviates salt stress-induced enhancement in ribulose1,5-bisphosphate oxygenase activity. Biochem. Biophys. Res. Commun. 279:512-515.

[57] Snedecor, G. W., and W. G. Cochran. 1990. "Statistical Methods". $8^{\text {th }}$ Ed. Iowa State Univ. Press Ames, Iowa, USA, p. 609.

[58] Southern, E. M. 1975. Detection of specific sequences among DNA fragments separated by gel electrophoresis. J. Molec. Biol. 98:503-517.

[59] Srivastava, A. K., N. K. Ramaswamy, P. Suprasanna, and S.F. D'Souza. 2010. Genome-wide analysis of thiourea-modulated salinity stress responsive transcripts in seeds of Brassica juncea: identification of signalling and effector components of stress tolerance. Ann. Bot. 106:663-674.

[60] Stoop, J. M. H., J. D. Williamson, and D. M. Pharr. 1996. Mannitol metabolism in plants: a method for coping with stress. Trends Plant Sci. 1:139-144.

[61] Su, J., P. L. Chen, and R. Wu. 1999. Transgene expression of mannitol-1-phosphate dehydrogenase enhanced the salt stress tolerance of the transgenic rice seedlings. Sci. Agric. Sin. 32:101-103.

[62] Taneja, S. R., and R. C. Sachar. 1974. Introduction of polyphenol oxidase in germinating wheat seeds. Phytochem. 13:2695-2702.

[63] Tarkowski, L.P., and W. Van den Ende. 2015. Cold tolerance triggered by soluble sugars: a multifaceted countermeasure. Fronti. Plant Sci. 6:1-7.

[64] Thomas, J. C., R. D. Armond, and H. J. Bohnert. 1992. Influnce of $\mathrm{NaCl}$ on growth, proline and phosphoenolpyruvate carboxylase levels in Mesembryanthemum crystallinum suspension cultures. Plant Physiol. 98:626-631.

[65] Thomas, J. C., M. Sepahi, B. Arendall, and H. J. Bohnert. 1996. Enhancement of seed germination in high salinity by engineering mannitol expression in Arabidopsis thaliana. Plant Cell Environ. 18:801-806. 
[66] Van den Ende, W., and S. El-Esawe. 2014. Sucrose signaling pathways leading to fructan and anthocyanin accumulation: a dual function in abiotic and biotic stress responses? Environ. Exp. Bot. 108:4-13.

[67] Van den Ende, W., and R. Valluru. 2009. Sucrose, sucrosyl oligosaccharides, and oxidative stress: scavenging and salvaging? J. Exp. Bot. 60:9-18.
[68] Weeks, J. T., O. D. Anderson, and A. E. Blechl. 1993. Rapid production of multiple independent lines of fertile transgenic wheat (Triticum aestivum). Plant Physiol. 102:1077-1084. 